Article

\title{
Characterization of Alistipes montrealensis sp. nov., Isolated from Human Feces of a Patient with Metastatic Melanoma Treated with Immune Checkpoint Inhibitors
}

\author{
Bertrand Routy ${ }^{1,2, *+\dagger}$, Corentin Richard ${ }^{1,+}$, Myriam Benlaïfaoui ${ }^{1}$, Simon Grandjean Lapierre ${ }^{1}$, \\ Nicholas Armstrong ${ }^{3}{ }^{1}$, Afnan Al-Saleh ${ }^{1}$, Mélodie Boko ${ }^{1}$, Maxime Jacq ${ }^{4}$, Ian R. Watson ${ }^{5,6}$, Catalin Mihalcioiu ${ }^{5}$, \\ Arielle Elkrief ${ }^{1}$, Maryam Tidjani Alou ${ }^{3}{ }^{\mathbb{D}}$, Meriem Messaoudene ${ }^{1}$ and Khoudia Diop ${ }^{1, * \mathbb{D}}$
}

check for updates

Citation: Routy, B.; Richard, C. Benlaïfaoui, M.; Lapierre, S.G.; Armstrong, N.; Al-Saleh, A.; Boko, M.; Jacq, M.; Watson, I.R.; Mihalcioiu, C.; et al. Characterization of Alistipes montrealensis sp. nov., Isolated from Human Feces of a Patient with Metastatic Melanoma Treated with Immune Checkpoint Inhibitors. Microbiol. Res. 2022, 13, 140-151. https://doi.org/10.3390/ microbiolres13010012

Academic Editor: Beniamino T. Cenci-Goga

Received: 18 December 2021 Accepted: 22 February 2022 Published: 26 February 2022

Publisher's Note: MDPI stays neutral with regard to jurisdictional claims in published maps and institutional affiliations.

Copyright: (C) 2022 by the authors. Licensee MDPI, Basel, Switzerland. This article is an open access article distributed under the terms and conditions of the Creative Commons Attribution (CC BY) license (https:// creativecommons.org/licenses/by/ $4.0 /)$
1 University of Montreal Research Center (CRCHUM), Montreal, QC H2X 0A9, Canada; corentin.richard@umontreal.ca (C.R.); myriam.benlaifaoui@umontreal.ca (M.B.); simon.grandjean.lapierre@umontreal.ca (S.G.L.); afnan.al-saleh.chum@ssss.gouv.qc.ca (A.A.-S.); melodie.boko@umontreal.ca (M.B.); arielle.elkrief.med@ssss.gouv.qc.ca (A.E.); meriem.messaoudene@umontreal.ca (M.M.)

2 Hematology-Oncology Division, Department of Medicine, University of Montreal Healthcare Centre (CHUM), Montreal, QC H2X 3E4, Canada

3 Aix Marseille Université, IHU-Méditerranée Infection, 13005 Marseille, France; nicholas.armstrong@univ-amu.fr (N.A.); tidjani_maryam@hotmail.com (M.T.A.)

4 Department of Microbiology and Immunology, Faculty of Medicine, University of Montreal, Montreal, QC H3C 3J7, Canada; maxime.jacq@umontreal.ca

5 Research Institute, McGill University Health Centre, Montreal, QC H4A 3J1, Canada; ian.watson2@mcgill.ca (I.R.W.); catalin.mihalcioiu.med@ssss.gouv.qc.ca (C.M.)

6 Rosalind and Morris Goodman Cancer Research Centre, McGill University, Montreal, QC H4A 3J1, Canada

* Correspondence: bertrand.routy@umontreal.ca (B.R.); khoudia.diop@umontreal.ca (K.D.); Tel.: +1-514-890-8000 (B.R. \& K.D.)

+ These authors contributed equally to this work.

\begin{abstract}
Fecal microbiome culturomics of a cancer patient treated with immune checkpoint inhibitors led to the identification of a Gram-negative, rod-shaped, obligate anaerobic, non-motile, non-sporeforming bacterium, designated strain $\mathrm{kh} 20^{\mathrm{T}}$, which was phylogenetically assigned to the genus Alistipes. Strain $\mathrm{kh} 20^{\mathrm{T}}$ demonstrated a $98.61 \% 16 \mathrm{~S}$ rRNA sequence similarity with $A$. shahii WAL $8301^{\mathrm{T}}$. The bacteria cells generated catalase but no oxidase. Iso- $\mathrm{C}_{15: 0}(26.6 \%)$, anteiso- $\mathrm{C}_{15: 0}(19.9 \%)$, and iso- $\mathrm{C}_{17: 0}(17.2 \%)$ were the major cellular fatty acids identified in its composition. The $\mathrm{G}+\mathrm{C}$ content of its genome was $57.2 \%$. Strain $\mathrm{kh} 20^{\mathrm{T}}$ showed significantly low values for DNA-DNA Hybridation (DDH $\leq 33.70 \%$ ) and Average Nucleotide Identity (ANI $\leq 86.35 \%$ ) compared with other Alistipes species. Based on these findings, we concluded that strain $\mathrm{kh} 20^{\mathrm{T}}$ represented a novel bacterium, and we proposed the name Alistipes montrealensis sp. nov. (CECT 30384 and CSUR Q6005).
\end{abstract}

Keywords: Alistipes; cancer; culturomics; gut microbiota; immunotherapy

\section{Introduction}

The development of immune checkpoint inhibitors (ICI) has revolutionized the therapeutic landscape for patients with advanced melanoma, non-small cell lung cancer (NSCLC), and renal cell carcinoma [1,2]. Strategies employing ICI, such as anti-programmed cell death receptor 1 (anti-PD-1) alone or in combination with anti-cytotoxic T lymphocyte antigen 4 (anti-CTLA-4) monoclonal antibodies, represent the standard of care in these malignancies. However, lack of T cell activation specificity toward cancer cells has been associated with important off-target immune-related adverse events (irAEs) [3]. These irAEs can involve any organ and represent a major therapeutic hurdle in immuno-oncology given their associated morbidity and mortality [1]. Evidence suggests that the gut microbiome regulates systemic immunity mediating ICI efficacy [4]. Indeed, antibiotics lead 
to dysbiosis which further associates with ICI resistance [5,6]. Moreover, early clinical evidence suggests that the gut microbiome may also regulate the development of irAEs [4].

Therefore, we initiated a microbiome culturomics-based study in order to isolate bacteria from patients treated with ICI that developed irAEs. In this ongoing study, we isolated an unknown bacterium that could not be identified at species level using MALDITOF mass spectrometry (MS) and 16S gene rRNA gene sequencing from a patient prior to ICI initiation. The strain was designated as strain $\mathrm{kh} 20^{\mathrm{T}}$, and its sequencing revealed it to be part of the genus Alistipes.

Affiliated to the phylum Bacteroidetes and the family of Rikenellaceae, the genus Alistipes was first described by Rautio et al. in 2003 (https:/ / lpsn.dsmz.de/genus / alistipes, accessed on 11 November 2021). Alistipes species colonize the gastro-intestinal tract and have been found to be overrepresented in patients that responded to ICI [7]. To date, fourteen Alistipes have been isolated from various human samples including feces, urine, and intraabdominal fluids [8-12]. Herein, the strain kh20 $0^{\mathrm{T}}$ isolated from the fecal sample of a metastatic melanoma patient was described by means of its phenotypic, phylogenetic, and genomic characteristics.

\section{Materials and Methods}

\subsection{Ethics and Sample Collection}

Strain $\mathrm{kh} 20^{\mathrm{T}}$ was isolated from a fecal sample of a 67-year-old woman with metastatic melanoma that developed a grade 3 colitis requiring corticosteroids. However, despite discontinuation of ICI, the patient had a sustained stable disease for 15 months and was still alive 18 months after ICI initiation. Signed informed consent was obtained at the time of sampling though the McGill University Health Centre Research Institute (MUHCRI) Biobank Ethics F9-69041 and the study was approved by the CHUM Research Ethics Committee 20.300. The fecal sample was collected on May 2019, prior to the first dose of anti-PD-1 treatment. Of note, the patient did not receive antibiotics within the last two months prior to sampling.

\subsection{Bacterial Strain Isolation and Identification}

To identify gut microbiota, culturomics was performed as previously described [13]. The fecal sample was diluted in $1 \mathrm{~mL}$ of Dulbecco's phosphate-buffered saline (dPBS) (Becton-Dickinson, Loveton Circle, MD, USA) and preincubated in a culture bottle (BectonDickinson) enriched with sterilized rumen fluid and sheep blood (Cedarlanelabs, Burlington, $\mathrm{ON}$, Canada) at $37^{\circ} \mathrm{C}$ for a period of 7 days. Next, $100 \mu \mathrm{L}$ of the broth was suspended in $900 \mu \mathrm{L}$ of dPBS and then serially diluted in steps 10-fold. Each dilution was then plated onto Tryptone soya agar (TSA) supplemented with 5\% sheep blood (OXOID, Nepean, Canada). Plates were incubated anaerobically at $37{ }^{\circ} \mathrm{C}$ for $5-7$ days in anaerobic jars (ThermoFisher, Waltham, MA, USA) using GENbag Anaer (Becton-Dickinson). To purify individually grown bacteria, all single macroscopic and microscopic colonies were picked and streaked out on TSA. After 2 days of anaerobic incubation at $37^{\circ} \mathrm{C}$, all isolates were identified using MALDI-TOF MS (Bruker Daltonics, Bremen, Germany).

MALDI-TOF MS was unable to identify strain $\mathrm{kh} 20^{\mathrm{T}}$. Therefore, the identification of strain $\mathrm{kh} 20^{\mathrm{T}}$ was carried out by sequencing its $16 \mathrm{~S}$ rRNA gene. The first step was a PCR amplification with the enzyme KAPA2G FAST, using the following cycles: $96^{\circ} \mathrm{C}$ for $1 \mathrm{~min}$, $96{ }^{\circ} \mathrm{C}$ for $10 \mathrm{~s}, 58^{\circ} \mathrm{C}$ for $5 \mathrm{~s}, 72{ }^{\circ} \mathrm{C}$ for $1 \mathrm{~s} 72{ }^{\circ} \mathrm{C}$ for $30 \mathrm{~s}$ and $4{ }^{\circ} \mathrm{C}$, respectively. The obtained PCR products were then purified with magnetic beads of type AMPure. The sequencing reaction, from these purified PCRs, was performed with BigDye ${ }^{\mathrm{TM}}$ Terminator v3.1 Cycle Sequencing Kit (ThermoFisher). The products of the sequencing reaction were purified with magnetic beads of the CleanSeq type, then read on 3730xl DNA Analyzer from Applied Biosystems $^{\mathrm{TM}}$. The sequence was then corrected using Chromas Pro software version 2.1.10 (Technelysium Pty. Ltd., South Brisbane, Australia). Strain kh20 ${ }^{\mathrm{T}}$ 's phylogenetic affiliation was subsequently investigated using the BLASTn program [14] and the nucleotide collection (nr/nt) of the NCBI database [15], available at https:/ / blast.ncbi.nlm.nih.gov/Blast.cgi 
(accessed on 11 November 2021). Sequence of our isolate and its related closest species were aligned using CLUSTAL W (available at https:/ / www.genome.jp/tools-bin/clustalw (accessed on 11 November 2021)) and the phylogenetic tree was constructed using Mega X software (available at https:/ /www.megasoftware.net/, accessed on 11 November 2021).

\subsection{Morphologic and Phenotypic Characteristics}

Strain $\mathrm{kh} 20^{\mathrm{T}}$ was cultured on TSA and incubated at various temperatures; 25, 28, 37,42 and $56{ }^{\circ} \mathrm{C}$, under anaerobic and microaerophilic atmospheres generated using GENbag Anaer and GENbag Microaer systems, respectively (Becton-Dickinson), and aerobic conditions, with or without $5 \%$ of $\mathrm{CO}_{2}$. After $48 \mathrm{~h}$ of incubation, growth on agar cultures was examined visually. Susceptibility of strain $\mathrm{kh} 20^{\mathrm{T}}$ to $\mathrm{NaCl}$ (concentrations of $0-100 \mathrm{~g} / \mathrm{L})$ and $\mathrm{pH}(5,6,6.5,7,7.5$ and 8.5) was tested.

Cells were subcultured and grown in Trypticase Soy Broth (TSB) at $37^{\circ} \mathrm{C}$ without shaking overnight. Cells' suspension was deposited on a glow-discharged formvar carbon film on 300 mesh copper grids (FCF300-CU, EMS). Cells were stained with $1 \%$ ammonium molybdate for $5 \mathrm{~s}$. Then bacterial cells' morphology was assessed by electronic microscope analysis using Tecnai G20 (FEI company, Hillsboro, OR, USA) and Gram-stain using a Gramstaining kit according to manufacturer's instructions (ThermoFisher). Gram-stain and cell mobility were observed using photonic microscope Motic AE2000 (Motic Microscope, Vancouver, BC, Canada). Sporulation was determined by subjecting the bacterium to thermal shock at $80{ }^{\circ} \mathrm{C}$ for $20 \mathrm{~min}$. Catalase and oxidase production was also detected (bioMérieux SA, Marcy l'Étoile, France). Enzymatic profile and biochemical properties of strain kh20 $0^{\mathrm{T}}$ were assessed using the $\mathrm{API}{ }^{\circledR} \mathrm{ZYM}$, API ${ }^{\circledR} 20 \mathrm{~A}$ and Rapid ID 32A identification systems according to the manufacturer's instructions (bioMérieux). Cellular fatty acid methyl ester profile was analysed using both gas chromatograph (Hewlett Packard) and Microbial Identification System (MIDI) software, version 6.0. End products were detected using a chromatograph as previously reported [9].

\subsection{Genome Sequencing and Annotation}

Genomic DNA was sequenced using MiSeq Illumina. Libraries were generated using the NxSeq ${ }^{\circledR}$ AmpFREE Low DNA Library Kit Library Preparation Kit (Lucigen, Parmenter, Middleton, WI, USA) according to the manufacturer's recommendations, with $700 \mathrm{ng}$ of genomic DNA as starting material. Dual-indexed adaptors were purchased from IDT. Libraries were quantified using the Kapa Illumina GA with the Revised Primers-SYBR Fast Universal kit (Kapa Biosystems, Ballardvale, MA, USA). Average size fragment was determined using a LabChip GX II (PerkinElmer, Waltham, MA, USA) instrument. The libraries were normalized and pooled, denatured in $0.05 \mathrm{~N} \mathrm{NaOH}$, and neutralized using HT1 buffer. The pool was loaded at $225 \mathrm{pM}$ on an Illumina NovaSeq S4 lane using $X \mathrm{p}$ protocol as per the manufacturer's recommendations. The run was performed for $2 \times 150$ cycles (paired-end mode). A phiX library was used as a control and mixed with libraries at the $1 \%$ level. Base calling was performed with RTA v3. Program bcl2fastq2 v2.20 was then used to demultiplex samples and generate fastq reads.

Quality control checks on raw sequences were performed with the FastQC software v0.11.9 [16]. Trimming and filtering were done through the Trimmomatic software v0.39 [17] using the following settings. The de novo genome assembly was made using the software SPAdes v3.15.2 [18] with the option-isolate. A final polishing of the draft genome assembly was performed with the Redundans software v0.13c [19] for gap closing and overlapped scaffolds merging with the options-identity 1-noreduction. Quality and completeness assessments of the genome assembly were made through BlobTools2 [20] and BUSCO $\mathrm{v} 4$ [21].

The bacterial proteome was predicted with NCBI Prokaryotic Genome Annotation Pipeline (PGAP) v5.2 [22] and the Best-placed reference protein set (GeneMarkS-2+) annotation method. Predicted protein was compared to the Clusters of Orthologous Groups (COG) 
database [23] using the Basic Local Alignment Search Tool for Protein (BlastP) v2.11.0+ [24] (E-value 1e-03, coverage 0.7 and identity percent 30 ).

The nucleotide sequences of the reference strains were obtained from the NCBI database. DNA-DNA hybridization $(\mathrm{DDH})$ values were evaluated by using a Genome-toGenome Distance Calculator (GGDC) [25]. In contrast, average nucleotide identity (ANI) values were calculated using the ANI calculator [26].

\section{Results}

\subsection{Strain Identification and Phylogenetic Analysis}

No MALDI-TOF identification of the strain $\mathrm{kh} 20^{\mathrm{T}}$ was obtained. Phylogenetic interferences based on $16 \mathrm{~S}$ rRNA gene sequences using the neighbor-joining method (Figures 1 and S1), revealed that strain $\mathrm{kh} 20^{\mathrm{T}}$ belongs to the genus Alistipes and is clustered with $A$. shahii WAL $8301^{\mathrm{T}}$ [10] and A. senegalensis JC50 ${ }^{\mathrm{T}}$ [27]. BLASTn analysis of the bacterium provided a $16 \mathrm{~S}$ rRNA nucleotide sequence identity of $98.61 \%$ with $A$. shahii WAL $8301^{\mathrm{T}}$. Its MALDITOF reference spectrum was incremented in our University of Montreal Research Center (CRCHUM) database.

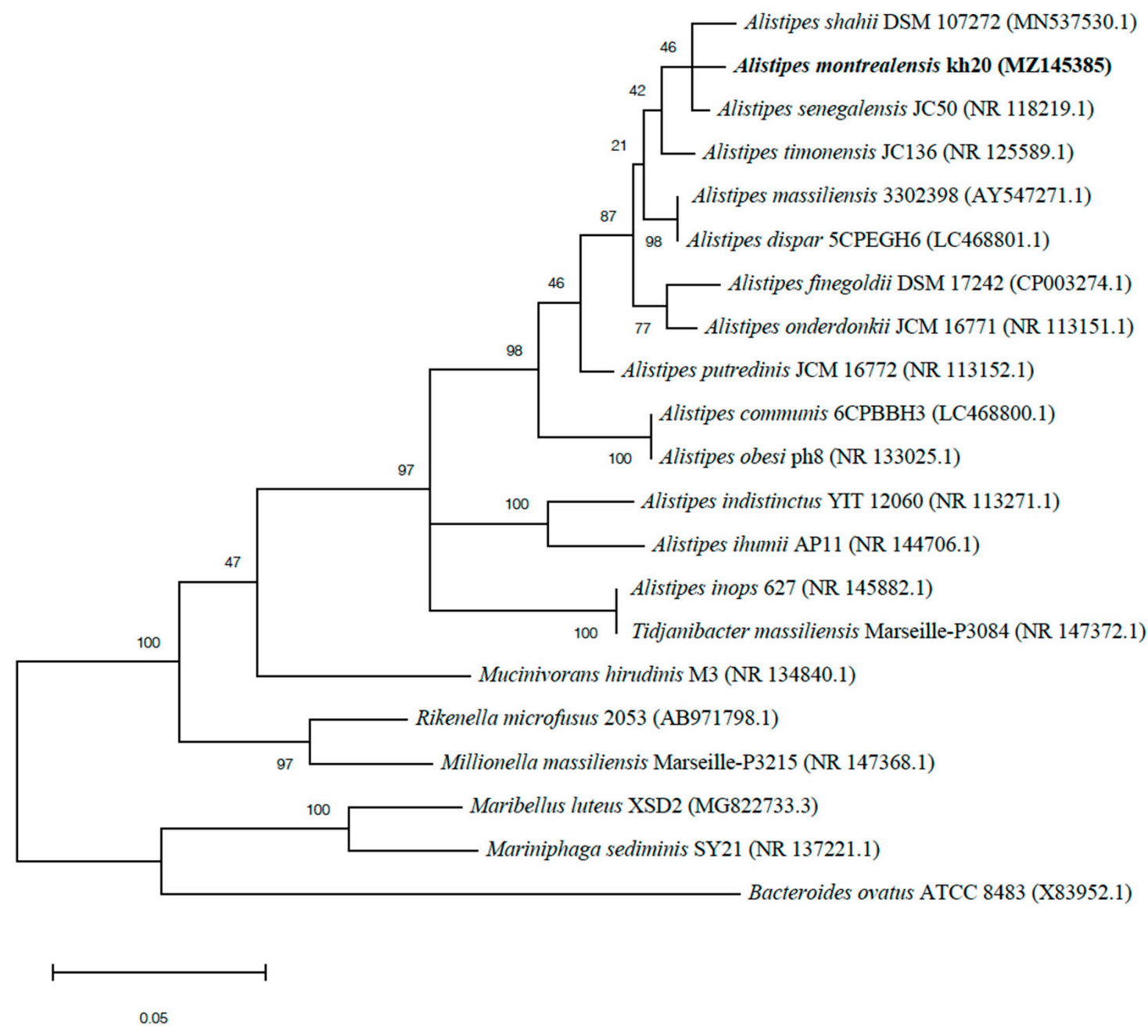

Figure 1. Phylogenetic tree highlighting the position of Alistipes montrealensis strain $\mathrm{kh} 20^{\mathrm{T}}$ relative to other closely related strains. GenBank accession numbers for each 16S rRNA are noted in parenthesis. Sequences were aligned using Muscle v3.8.31 with default parameters and phylogenetic inferences were obtained using the neighbor joining method with 500 bootstrap replicates, using MEGAX software. The scale bar represents a $5 \%$ nucleotide sequence divergence. 


\subsection{Phenotypic Features}

Cells of strain $\mathrm{kh} 20^{\mathrm{T}}$ were non-motile, non-spore-forming, obligate anaerobes and Gram-negative rod-shaped. When inoculated on TSA, cells grew mostly singly and were $0.7 \times 2.5 \mu \mathrm{m}$ in size (Figure 2). After $48 \mathrm{~h}$ of growth on TSA, the colonies increased in size $\left(0.2-0.3 \mathrm{~mm}\right.$ in diameter) and were grey, circular, and convex. Strain $\mathrm{kh} 20^{\mathrm{T}}$ was grown in an anaerobic atmosphere at $\mathrm{pH} 6$ and $7.5, \mathrm{NaCl}$ concentration less than $5 \mathrm{~g} / \mathrm{L}$, and temperatures between $28-37^{\circ} \mathrm{C}$. Strain $\mathrm{kh} 20^{\mathrm{T}}$ exhibited positive catalase activity, and negative oxidase and urease activity. Nitrate was not reduced to nitrite. Bile was resistant. Using $\mathrm{API}^{\circledR} \mathrm{ZYM}$ and Rapid 32A strips, positive enzyme reactions were obtained for alkaline phosphatase, galactosidase ( $\alpha$ and $\beta$ ), $\beta$-glucosidase and $N$-acetyl- $\beta$-glucosaminidase. In addition, esterase, esterase lipase, acid phosphatase and naphthol-AS-BI-phosphohydrolase were detected on $\mathrm{API}^{\circledR} \mathrm{ZYM}$. When tested with Rapid 32A strips, positive reactions were also obtained for glutamyl glutamic acid arylamidase, glutamic acid decarboxylase, proline arylamidase, leucyl glycine arylamidase, phenylalanine arylamidase, tyrosine arylamidase, alanine arylamidase, and glycine arylamidase. According to the $\mathrm{API}^{\circledR} 20 \mathrm{~A}$ kit, strain kh20 ${ }^{\mathrm{T}}$ hydrolyzed esculin and fermented D-glucose, D-lactase, glycerol, D-cellobiose, D-mannose, D-raffinose, and L-rhamnose. All other tests were negative (Table 1). Chemotypic analysis showed that strain $\mathrm{kh} 20^{\mathrm{T}}$ was primarily composed of cellular fatty acids (Table 2) iso$\mathrm{C}_{15: 0}(26.60 \%)$, anteiso- $\mathrm{C}_{15: 0}(19.90 \%)$, iso- $\mathrm{C}_{17: 0}(17.20 \%)$, and anteiso- $\mathrm{C}_{17: 0}(10.80 \%)$. Minor amounts of other fatty acids were also present, including $C 16: 0(8.50 \%)$, iso- $C_{16: 0}(4.42 \%)$, iso- $\mathrm{C}_{15: 0} 3 \mathrm{OH}(1.76 \%), \mathrm{C}_{18: 0}(1.42 \%)$ and $\mathrm{C}_{15: 0 \mathrm{w} 5 \mathrm{c}}(1.30 \%)$. In addition, strain kh20 produced $\mathrm{CO}_{2}$, hydrogen and ethanol. Main phenotypic characteristics of strain $\mathrm{kh} 20^{\mathrm{T}}$ and those of its closely related neighbors are shown in Table 1 . We acknowledge the fact that the comparison of fatty acid profiles may not be easily done between studies due to differences in the composition of media, age of the culture, temperature, and the availability of oxygen.

Table 1. Differential phenotypic features between strain $\mathrm{kh} 20^{\mathrm{T}}$ and closest related species [9]. 1, A. montrealensis kh20 $; 2$, A. shahii JCM 16773 $; 3$, A. finegoldii JCM 16770 $; 4$, Alistipes dispar 5CPEGH6 ${ }^{\mathrm{T}} ; 5$, A. onderdonkii JCM $16771 \mathrm{~T}^{\mathrm{T}} ; 6$, A. timonensis JCM $32780^{\mathrm{T}} ; 7$, A. putridinis JCM $16772^{\mathrm{T}}$. + , Positive; - , negative; and $\mathrm{W}$, weak.

\begin{tabular}{|c|c|c|c|c|c|c|c|}
\hline Character & 1 & 2 & 3 & 4 & 5 & 6 & 7 \\
\hline Indole production & + & $\mathrm{w}$ & + & $\mathrm{w}$ & + & $\mathrm{w}$ & + \\
\hline Nitrate reduction & - & - & - & - & - & - & - \\
\hline Catalase & + & + & - & - & - & + & + \\
\hline Aesculin hydrolysis & + & + & - & - & $\mathrm{v}$ & + & - \\
\hline Gelatin digestion & - & $\mathrm{w}$ & + & $\mathrm{w}$ & + & - & $\mathrm{w}$ \\
\hline \multicolumn{8}{|l|}{ Enzyme activities } \\
\hline Alkaline phosphatase & + & + & + & + & + & $\mathrm{w}$ & + \\
\hline $\begin{array}{c}\text { N-acetyl- } \beta \text { - } \\
\text { glucosaminidase }\end{array}$ & + & + & + & + & + & + & - \\
\hline$\beta$-Galactosidase & + & + & + & + & + & + & - \\
\hline$\beta$-Glucosidase & + & w & - & - & - & + & - \\
\hline \multicolumn{8}{|l|}{ Fermentation of } \\
\hline Cellobiose & + & $\mathrm{w}$ & w & $\mathrm{w}$ & $\mathrm{w}$ & + & - \\
\hline Glucose & + & $\mathrm{w}$ & + & $\mathrm{w}$ & $\mathrm{w}$ & + & - \\
\hline Lactose & + & + & + & + & $\mathrm{w}$ & + & - \\
\hline Mannitol & - & - & - & $\mathrm{w}$ & $\mathrm{w}$ & $\mathrm{w}$ & - \\
\hline Mannose & + & + & + & + & + & + & - \\
\hline Raffinose & + & + & $\mathrm{w}$ & + & $\mathrm{w}$ & + & - \\
\hline Rhamnose & + & w & - & w & + & + & - \\
\hline Major Fatty acids & $\begin{array}{l}\text { iso- } C_{15: 0} \\
\text { anteiso- } C_{15: 0} \\
\text { iso- } C_{17: 0}\end{array}$ & $\begin{array}{c}\text { iso- } C_{15: 0} \\
C_{15: 0} \\
C_{18: 1 \omega 9 c}\end{array}$ & $\begin{array}{l}\text { iso- } C_{15: 0} \\
C_{18: 1 \omega 9 c} \\
C_{16: 0}\end{array}$ & $\begin{array}{l}\text { iso- } C_{15: 0} \\
C_{18: 1 \omega 9 c} \\
C_{16: 0}\end{array}$ & $\begin{array}{c}\text { iso- } C_{15: 0} \\
C_{18: 1 \omega 9 c} \\
C_{16: 0}\end{array}$ & $\begin{array}{l}\text { iso- } C_{15: 0} \\
C_{18: 1 \omega 9 c} \\
C_{16: 0}\end{array}$ & $\begin{array}{c}\text { iso- }_{15: 0} \\
\mathrm{C}_{18: 1 \omega 9 \mathrm{c}} \\
\text { Summed } \\
\text { feature }\end{array}$ \\
\hline
\end{tabular}


Table 2. Cellular fatty acid composition (\%) of strain kh20

\begin{tabular}{|c|c|}
\hline Fatty Acids & Percent \\
\hline iso- $\mathrm{C}_{11: 0}$ & 0.35 \\
\hline iso- $C_{13: 0}$ & 0.30 \\
\hline iso- $\mathrm{C}_{14 \cdot 0}$ & 0.82 \\
\hline $\mathrm{C}_{14: 0}$ & 0.89 \\
\hline iso-C $15: 0$ & 26.60 \\
\hline anteiso- $\mathrm{C}_{15: 0}$ & 19.92 \\
\hline $\mathrm{C}_{15: 0 \mathrm{w} 5 \mathrm{C}}$ & 1.30 \\
\hline iso- $\mathrm{C}_{14: 0} 3 \mathrm{OH}$ & 0.55 \\
\hline iso- $\mathrm{C}_{16: 0}$ & 4.42 \\
\hline$C_{16: 1 \text { w9c }}$ & 0.31 \\
\hline $\mathrm{C}_{16: 1 \mathrm{w} 5 \mathrm{c}}$ & 0.23 \\
\hline $\mathrm{C}_{16: 0}$ & 8.50 \\
\hline iso- $\mathrm{C}_{15: 0} 3 \mathrm{OH}$ & 1.76 \\
\hline $\mathrm{C}_{15: 0} 2 \mathrm{OH}$ & 0.77 \\
\hline iso- $\mathrm{C}_{17: 1 \mathrm{w} 10 \mathrm{c}}$ & 0.26 \\
\hline iso- $\mathrm{C}_{17: 0}$ & 17.21 \\
\hline anteiso- $\mathrm{C}_{17: 0}$ & 10.80 \\
\hline $\mathrm{C}_{16: 0} 3 \mathrm{OH}$ & 0.83 \\
\hline $\mathrm{C}_{18: 3 \mathrm{w} 6 \mathrm{C}}$ & 0.19 \\
\hline iso- $C_{18: 0}$ & 0.24 \\
\hline $\mathrm{C}_{18: 1 \mathrm{w} 9 \mathrm{C}}$ & 0.43 \\
\hline $\mathrm{C}_{18: 0}$ & 1.42 \\
\hline iso- $\mathrm{C}_{17: 0} 3 \mathrm{OH}$ & 0.54 \\
\hline iso- $\mathrm{C}_{19: 0}$ & 0.64 \\
\hline anteiso- $C_{19: 0}$ & 0.33 \\
\hline
\end{tabular}

Predominant products are shown in bold.

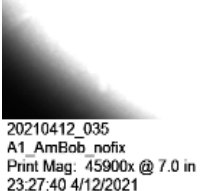

Print Mag: $45900 x$ @ 7.0

Microscopist: MontUsers

Camera: XR280, Exposure(ms): 1200.0 Gain: 1, Bin: 1

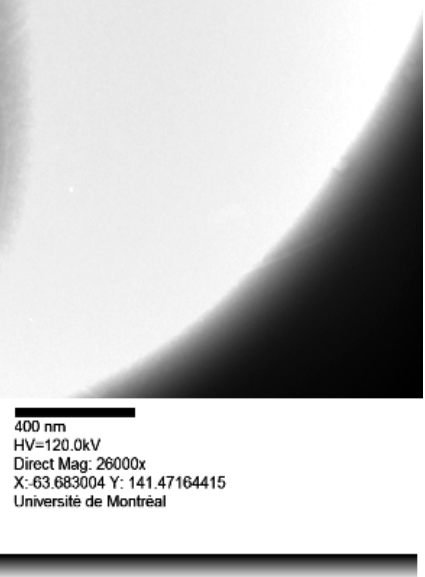

Figure 2. Transmission electron microscopy of Alistipes montrealensis strain kh20 $20^{\mathrm{T}}$ using a Tecnai G20 transmission electron microscope. 


\subsection{Genome Characteristics}

A summary of the genome assembly is shown in Figure S2. Briefly, the draft genome of strain $\mathrm{kh} 20^{\mathrm{T}}$ (accession number JAGYXY000000000.1) was constituted of 13 scaffolds and $3,484,450$ bp in length with $57.231 \%$ of $\mathrm{G}+\mathrm{C}$ content. This draft assembly included $92.70 \%$ of the orthologous groups of the Bacteria kingdom, and $97 \%$ of the Bacteroidales order. Of the 2778 predicted genes, 2700 were protein-coding genes and 54 were RNA genes (one 5S rRNA, one 16S rRNA, one 23S rRNA, three ncRNA and 48 tRNA genes). A total of 2065 genes $(76 \%)$ were assigned a putative function by clusters of orthologous groups (COGs). The distribution of the predicted gene into the 25 general COGs is summarized in Table 3. A summary of the repartition of these predicted genes is presented in Figure 3.

Table 3. Number of genes associated with the 25 general cluster of orthologous group (COG) functional categories.

\begin{tabular}{|c|c|c|c|}
\hline Code & Value & $\%$ Value & Description \\
\hline $\mathrm{J}$ & 193 & 7.15 & Translation, ribosomal structure, and biogenesis \\
\hline $\mathrm{A}$ & 0 & 0 & RNA processing and modification \\
\hline K & 134 & 4.96 & Transcription \\
\hline $\mathrm{L}$ & 124 & 4.59 & Replication, recombination, and repair \\
\hline $\mathrm{B}$ & 0 & 0 & Chromatin structure and dynamics \\
\hline $\mathrm{D}$ & 50 & 1.85 & Cell cycle control, cell division, chromosome partitioning \\
\hline $\mathrm{Y}$ & 0 & 0 & Nuclear structure \\
\hline $\mathrm{V}$ & 53 & 1.96 & Defense mechanisms \\
\hline $\mathrm{T}$ & 183 & 6.78 & Signal transduction mechanisms \\
\hline M & 263 & 9.74 & Cell wall/membrane/envelope biogenesis \\
\hline $\mathrm{N}$ & 32 & 1.19 & Cell motility \\
\hline $\mathrm{Z}$ & 0 & 0 & Cytoskeleton \\
\hline W & 0 & 0 & Extracellular structures \\
\hline $\mathrm{U}$ & 34 & 1.26 & Intracellular trafficking, secretion, and vesicular \\
\hline $\mathrm{O}$ & 110 & 4.07 & $\begin{array}{c}\text { Posttranslational modification, protein turnover, } \\
\text { chaperones }\end{array}$ \\
\hline$X$ & 15 & 0.56 & Mobilome: prophages, transposons \\
\hline $\mathrm{C}$ & 168 & 6.22 & Energy production and conversion \\
\hline G & 236 & 8.74 & Carbohydrate transport and metabolism \\
\hline $\mathrm{E}$ & 139 & 5.15 & Amino acid transport and metabolism \\
\hline $\mathrm{F}$ & 67 & 2.48 & Nucleotide transport and metabolism \\
\hline $\mathrm{H}$ & 113 & 4.19 & Coenzyme transport and metabolism \\
\hline $\mathrm{I}$ & 84 & 3.11 & Lipid transport and metabolism \\
\hline $\mathrm{P}$ & 174 & 6.44 & Inorganic ion transport and metabolism \\
\hline Q & 19 & 0.70 & $\begin{array}{l}\text { Secondary metabolites biosynthesis, transport, and } \\
\text { carbohydrate }\end{array}$ \\
\hline $\mathrm{R}$ & 197 & 7.30 & General function prediction only \\
\hline S & 70 & 2.59 & Function unknown \\
\hline- & 242 & 8.97 & Not in COGs \\
\hline
\end{tabular}

The genomic comparison of strain $\mathrm{kh} 20^{\mathrm{T}}$ with those of its closest neighbors is detailed in Table 4 and illustrated in Figure 4. The genome size, DNA G+C percentage and gene content of strain $\mathrm{kh} 20^{\mathrm{T}}(3.48 \mathrm{Mb}, 57.20 \mathrm{~mol} \%$ and 2700 , respectively) are in the same range of those of compared species, but very close to those of $A$. timonensis $(3.49 \mathrm{Mb}, 58.8 \%$ and 2764, respectively). However, strain $\mathrm{kh} 20^{\mathrm{T}}$ shows a genomic difference of $1.60 \%$ in $\mathrm{G}+\mathrm{C}$ content compared to $A$. timonensis. Pairwise whole-genome ANI and DDH between strain $\mathrm{kh} 20^{\mathrm{T}}$ and its closest related species is itemized in Table 5. The obtained ANI values among compared species ranged from $74.29 \%$ (A. timonensis / A. putridinis) to $84.76 \%$ (A. timonensis/A. shahii). The genome of strain $\mathrm{kh} 20^{\mathrm{T}}$ share ANI values from $74.18 \%$ with A. timonensis to $86.35 \%$ with $A$. shahii. Calculated DDH are ranked from $21.40 \pm 2.35$ (A. timonensis/A. putridinis) to $32.00 \pm 2.50$ (A. timonensis/A. shahii). The genome of strain 
kh20 $20^{\mathrm{T}}$ showed particularly low consistency with other Alistipes species' genomes, with DDH values from $21.70 \pm 2.35$ with $A$. putridinis to $33.70 \pm 2.50 \%$ with $A$. shahii.

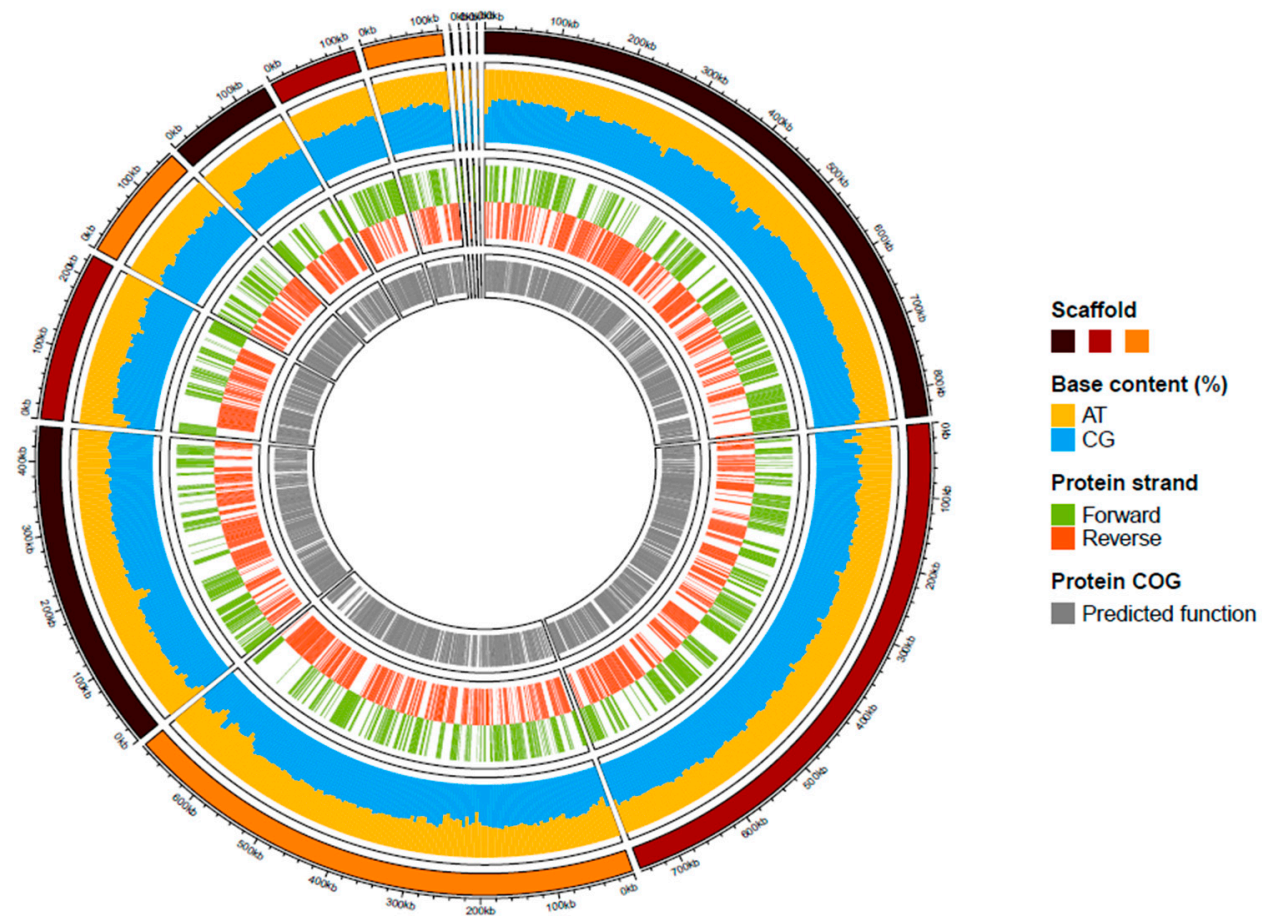

Figure 3. Graphical circular map of the genome of strain $k h 20^{\mathrm{T}}$. From outside to the center: Scaffolds (brown/dark red/orange), AT and GC contents (yellow/blue), predicted proteins on the forward or reverse strands (green/ dark orange), predicted protein with a functional COG category.

Table 4. Genome comparison of closely related species to strain $\mathrm{kh} 20^{\mathrm{T}}$.

\begin{tabular}{|c|c|c|c|c|c|}
\hline Species & Strain & INSDC ${ }^{a}$ Identifier & Size $(\mathbf{M b})$ & GC Percent & Gene Content \\
\hline Alistipes montrealensis & kh20 & JAGYXY000000000.1 & 3.48 & 57.20 & 2700 \\
\hline Alistipes shahii & WAL 8301 & FP929032.1 & 3.76 & 57.20 & 3152 \\
\hline Alistipes finegoldii & DSM 17242 & СР003274.1 & 3.73 & 56.60 & 3236 \\
\hline Alistipes dispar & 5CPEGH6 & AP019736.1 & 2.96 & 61.30 & 2475 \\
\hline Alistipes onderdonkii & DSM 19147 & ARFY00000000.1 & 3.87 & 57.80 & 3217 \\
\hline Alistipes timonensis & DSM 25383 & FNRI00000000.1 & 3.49 & 58.80 & 2764 \\
\hline Alistipes putridinis & DSM 17216 & ABFK00000000.2 & 2.55 & 53.30 & 2334 \\
\hline
\end{tabular}

${ }^{a}$ INSDC: International Nucleotide Sequence Database Collaboration.

Table 5. Genomic comparison. DNA-DNA hybridization (DDH, upper right side) and Average Nucleotide Identity (ANI, lower left side) values calculated between strain $\mathrm{kh} 2 \mathrm{O}^{\mathrm{T}}$ and closest related species.

\begin{tabular}{|c|c|c|c|c|c|c|c|}
\hline & A. montrealensis & A. shahii & A. finegoldii & A. dispar & A. onderdonkii & A. timonensis & A. putridinis \\
\hline A. montrealensis & - & $33.70 \pm 2.50$ & $24.60 \pm 2.40$ & $24.10 \pm 2.35$ & $23.60 \pm 2.40$ & $28.50 \pm 2.40$ & $21.70 \pm 2.35$ \\
\hline A. shahii & 86.35 & - & $30.50 \pm 2.45$ & $26.20 \pm 2.45$ & $29.80 \pm 2.45$ & $32.00 \pm 2.50$ & $26.00 \pm 2.40$ \\
\hline A. finegoldi & 78.92 & 81.98 & - & $24.00 \pm 2.40$ & $30.50 \pm 2.45$ & $24.90 \pm 2.40$ & $25.10 \pm 2.40$ \\
\hline A. dispar & 79.15 & 80.59 & 79.00 & - & $23.40 \pm 2.40$ & $24.70 \pm 2.40$ & $23.30 \pm 2.40$ \\
\hline A. onderdonkii & 78.62 & 82.23 & 83.47 & 78.62 & - & $24.80 \pm 2.40$ & $24.40 \pm 2.40$ \\
\hline A. timonensis & 83.03 & 84.76 & 79.55 & 83.03 & 79.39 & - & $21.40 \pm 2.35$ \\
\hline A. putrididnis & 74.18 & 75.19 & 75.87 & 75.04 & 75.16 & 74.29 & - \\
\hline
\end{tabular}




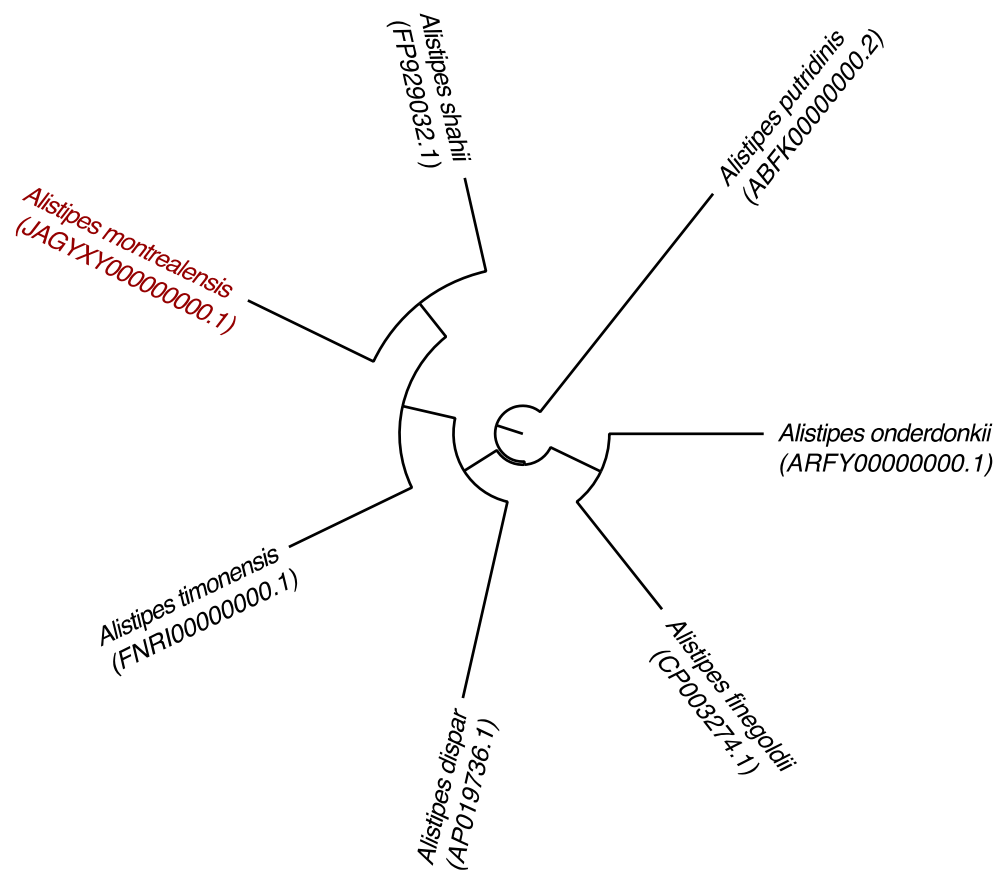

Figure 4. Phylogenetic tree based on whole genome sequence showing the position of Alistipes montrealensis strain $\mathrm{kh} 20^{\mathrm{T}}$ relative to its nearest neighbors. GenBank accession numbers are indicated in parentheses. Sequences were aligned using Mugsy software, and phylogenetic inferences were performed using the maximum likelihood method with the software FastTree. The scale bar represents a $2 \%$ nucleotide sequence divergence.

\section{Discussions}

Strain $\mathrm{kh} 20^{\mathrm{T}}$ was isolated as part of a project to study the role of the gut microbiota in the efficacy of ICI treatment. Phenotypic, phylogenetic, and genomic comparison between strain $\mathrm{kh} 20^{\mathrm{T}}$ and its most closely related species was performed. The combination of these phylogenetic (Figures 1 and S1), phenotypic (Tables 1 and 2) and genomic characteristics (Figure 4 and Tables 3-5) indicates that strain $\mathrm{kh} 20^{\mathrm{T}}$ belongs in the family of Rikenellaceae, within the Alistipes genus. However, it can be easily distinguished from other Alistipes species on the basis of its phenotypic features, such as its major cellular fatty acids composition (Tables 1 and 2). Moreover, its genomic data, especially its low DDH values (between $21.70 \%$ with $A$. putridinis to $33.70 \%$ with $A$. shahii), and ANI percentages (between $74.18 \%$ with $A$. putridinis to $86.35 \%$ with $A$. shahii) below the $70 \%$ and $95 \%$ thresholds $[25,28-30]$, respectively, for bacterial species demarcation indicate that kh20 $20^{\mathrm{T}}$ is a member of a genomic species different from any of its neighbors. In addition, its sequence similarity value of the $16 \mathrm{~S}$ rRNA gene $(98.61 \%)$, which is lower than the $98.65 \%$ threshold for distinguishing two species [31-33], supports the classification of strain $\mathrm{kh} 20^{\mathrm{T}}$ as a new species of the genus Alistipes.

Created in 2003 by Ratio, the genus Alistipes regroups to date 16 species isolated in human sources and mainly in gastrointestinal tract. From a clinical perspective, Alistipes have been associated with beneficial clinical outcomes [4] and oral supplementation in mice restored anti-PD-1 efficacy [34]. In addition, Alistipes species are known to be enriched in non-small cell lung cancer with detectable Akkermansia correlating with longer overall survival [35]. Additional studies are needed to further delineate the role of Alistipes in the incidence of immune-related colitis and to better understand the paradoxical association between irAEs and improved survival. 


\section{Conclusions}

Based on phylogenetic analysis, phenotypic data and genomic comparisons, the strain kh2 $20^{\mathrm{T}}$ differs sufficiently from its closest related species to be classified as a new species of the genus Alistipes. The name Alistipes montrealensis sp. nov. is proposed for this new taxon. It was isolated from a stool sample of a melanoma patient treated with ICI.

Description of Alistipes montrealensis sp. nov.

Alistipes montrealensis (mon.treal.e'n.sis. L. gen. masc. n. montrealensis, pertaining to Montreal, the city where the type of strain was first isolated).

Cells are strictly anaerobic, asporogenous, non-motile, rod-shaped, approximately $0.7 \times 2.5 \mu \mathrm{m}$ in diameter and grow singly. Cultures are mesophilic (optimal at $37{ }^{\circ} \mathrm{C}$ ), tolerate a low concentration of $\mathrm{NaCl}$ (below $5 \mathrm{~g} / \mathrm{L}$ ) and a $\mathrm{pH}$ between 6 and 7.5. After $48 \mathrm{~h}$ of incubation on TSA under an anaerobic atmosphere, colonies seem grey, circular, and convex with $0.2-0.3 \mathrm{~mm}$ of diameter. Catalase and indole are produced, esculin is hydrolyzed, nitrate is not reduced, gelatin is not digested and production of both oxidase and urease are negative. Acid is produced from D-glucose, D-lactase, glycerol, D-cellobiose, D-mannose, D-raffinose, and L-rhamnose. Positive reactions are observed for alkaline phosphatase, galactosidase ( $\alpha$ and $\beta$ ), $\beta$-glucosidase, N-acetyl- $\beta$-glucosaminidase, esterase, esterase lipase, acid phosphatase, naphthol-AS-BI-phosphohydrolase. The major cellular fatty acids composing the strain are iso- $C_{15: 0}(26.60 \%)$, anteiso- $C_{15: 0}(19.90 \%)$, and iso- $C_{17: 0}$ $(17.20 \%)$.

The type of strain $\mathrm{kh} 20^{\mathrm{T}}$ (CECT 30384 and CSUR Q6005) was isolated from a faecal sample of a cancer patient. It is susceptible to metronidazole but resistant to colistin, kanamycin, and vancomycin. Its genome is 3,484,450 bp in length and exhibits $57.20 \mathrm{~mol} \%$ of $\mathrm{G}+\mathrm{C}$. The $16 \mathrm{~S}$ rRNA and genome sequences are deposited in GenBank under accession numbers MZ145385 and JAGYXY000000000, respectively. The habitat is probably the human gut.

Supplementary Materials: The following are available online at https: / www.mdpi.com/article/ 10.3390/microbiolres13010012/s1, Figure S1: Maximum likelihood phylogenetic tree based on 16S rRNA sequences, Figure S2: Snail plot summary of assembly statistics for the genome assembly.

Author Contributions: Methodology: B.R. and K.D.; validation, B.R., C.R. and K.D.; investigation: M.B. (Myriam Benlaïfaoui), S.G.L., N.A., M.B. (Mélodie Boko), M.J., I.R.W., C.M., A.E. and M.T.A.; data curation: B.R., C.R. and K.D.; formal analysis, C.R. and K.D.; visualization: C.R. and K.D.; writing—original draft preparation: B.R. and K.D.; writing—review and editing, B.R., A.A.-S., M.M. and K.D.; supervision, B.R. and K.D. All authors read and approved the final manuscript. All authors have read and agreed to the published version of the manuscript.

Funding: The study is funded by the Canadian Institutes of Health Research (CIHR) and "Fonds de recherche du Québec-Santé" under agreements 420356 and 284894, respectively. This work was supported by the Electron Imaging Facility, Faculty of Dental Medicine, University of Montréal.

Institutional Review Board Statement: This study was approved by the Ethics Committee of CHUM Research under agreement number 20.300.

Informed Consent Statement: Each subject gave an informed and signed consent for this study.

Data Availability Statement: The datasets presented in this study can be found in online repositories. Associated accession numbers are cited in the manuscript.

Acknowledgments: The authors are grateful to Wiam Belkaid, Julie Malo and Laurent Knafo for their help in the realisation of this research project. The authors would also like to thank CRCHUM, Terry Fox Research Institute (TFRI) Montreal Cancer Consortium pilot project (TFRI-Grant \#1084), the RI-MUHC Skin Lesion Biobank platform, Electron Imaging Facility (Faculty of Dental Medicine, UdeM) and the University of Montreal for their financial support.

Conflicts of Interest: The authors declare no conflict of interest. 


\begin{tabular}{ll}
\multicolumn{2}{l}{ Abbreviations } \\
ANI & Average Nucleotide Identity \\
anti-CTLA-4 & Anti-cytotoxic T lymphocyte antigen 4 \\
anti-PD-1 & Anti-programmed cell death receptor 1 \\
CECT & Colección Española de Cultivos Tipo \\
CSUR & Collection de souches de l'Unité des Rickettsies \\
DDH & DNA-DNA hybridization \\
ICI & Immune checkpoint inhibitors \\
irAE & Immune-related adverse events \\
MALDI-TOF & Matrix-assisted laser desorption/ionization time-of-flight \\
MS & Mass spectrometry \\
ORR & Overall response rate
\end{tabular}

\section{References}

1. Larkin, J.; Chiarion-Sileni, V.; Gonzalez, R.; Grob, J.-J.; Rutkowski, P.; Lao, C.D.; Cowey, C.L.; Schadendorf, D.; Wagstaff, J.; Dummer, R.; et al. Five-year survival with combined nivolumab and ipilimumab in advanced melanoma. N. Engl. J. Med. 2019, 381, 1535-1546. [CrossRef] [PubMed]

2. $\quad$ Elkrief, A.; Joubert, P.; Florescu, M.; Tehfe, M.; Blais, N.; Routy, B. Therapeutic landscape of metastatic non-small-cell lung cancer in Canada in 2020. Curr. Oncol. Tor. Ont. 2020, 27, 52-60. [CrossRef]

3. Esfahani, K.; Elkrief, A.; Calabrese, C.; Lapointe, R.; Hudson, M.; Routy, B.; Miller, W.H.; Calabrese, L. Moving towards personalized treatments of immune-related adverse events. Nat. Rev. Clin. Oncol. 2020, 17, 504-515. [CrossRef] [PubMed]

4. Routy, B.; Gopalakrishnan, V.; Daillère, R.; Zitvogel, L.; Wargo, J.A.; Kroemer, G. The gut microbiota influences anticancer immunosurveillance and general health. Nat. Rev. Clin. Oncol. 2018, 15, 382-396. [CrossRef] [PubMed]

5. $\quad$ Elkrief, A.; El Raichani, L.; Richard, C.; Messaoudene, M.; Belkaid, W.; Malo, J.; Belanger, K.; Miller, W.; Jamal, R.; Letarte, N.; et al. Antibiotics are associated with decreased progression-free survival of advanced melanoma patients treated with immune checkpoint inhibitors. Oncoimmunology 2019, 8, e1568812. [CrossRef] [PubMed]

6. Hakozaki, T.; Richard, C.; Elkrief, A.; Hosomi, Y.; Benlaïfaoui, M.; Mimpen, I.; Terrisse, S.; Derosa, L.; Zitvogel, L.; Routy, B.; et al. The gut microbiome associates with immune checkpoint inhibition outcomes in patients with advanced non-small cell lung cancer. Cancer Immunol. Res. 2020, 8, 1243-1250. [CrossRef] [PubMed]

7. Parker, B.J.; Wearsch, P.A.; Veloo, A.C.M.; Rodriguez-Palacios, A. The genus Alistipes: Gut bacteria with emerging implications to inflammation, cancer, and mental health. Front. Immunol. 2020, 11, 906. [CrossRef] [PubMed]

8. Shkoporov, A.N.; Chaplin, A.V.; Khokhlova, E.V.; Shcherbakova, V.A.; Motuzova, O.V.; Bozhenko, V.K.; Kafarskaia, L.I.; Efimov, B.A. Alistipes inops sp. nov. and Coprobacter secundus sp. nov., isolated from human faeces. Int. J. Syst. Evol. Microbiol. 2015, 65, 4580-4588. [CrossRef] [PubMed]

9. Sakamoto, M.; Ikeyama, N.; Ogata, Y.; Suda, W.; Iino, T.; Hattori, M.; Ohkuma, M. Alistipes communis sp. nov., Alistipes dispar sp. nov. and Alistipes onderdonkii subsp. Vulgaris subsp. nov., isolated from human faeces, and creation of Alistipes onderdonkii subsp. onderdonkii subsp. nov. Int. J. Syst. Evol. Microbiol. 2020, 70, 473-480. [CrossRef] [PubMed]

10. Song, Y.; Könönen, E.; Rautio, M.; Liu, C.; Bryk, A.; Eerola, E.; Finegold, S.M.Y. Alistipes onderdonkii Sp. nov. and Alistipes shahii sp. nov., of human origin. Int. J. Syst. Evol. Microbiol. 2006, 56, 1985-1990. [CrossRef]

11. Rautio, M.; Eerola, E.; Väisänen-Tunkelrott, M.-L.; Molitoris, D.; Lawson, P.; Collins, M.D.; Jousimies-Somer, H. Reclassification of Bacteroides Putredinis (Weinberg et al., 1937) in a new genus Alistipes gen. nov., as Alistipes putredinis comb. nov., and description of Alistipes finegoldii sp. nov., from human sources. Syst. Appl. Microbiol. 2003, 26, 182-188. [CrossRef]

12. Lagier, J.-C.; Armougom, F.; Mishra, A.K.; Nguyen, T.-T.; Raoult, D.; Fournier, P.-E. Non-contiguous finished genome sequence and description of Alistipes timonensis sp. nov. Stand. Genom. Sci. 2012, 6, 315-324. [CrossRef] [PubMed]

13. Lagier, J.-C.; Armougom, F.; Million, M.; Hugon, P.; Pagnier, I.; Robert, C.; Bittar, F.; Fournous, G.; Gimenez, G.; Maraninchi, M.; et al. Microbial Culturomics: Paradigm shift in the human gut microbiome study. Clin. Microbiol. Infect. 2012, 18, 1185-1193. [CrossRef] [PubMed]

14. Altschul, S.F.; Madden, T.L.; Schäffer, A.A.; Zhang, J.; Zhang, Z.; Miller, W.; Lipman, D.J. Gapped BLAST and PSI-BLAST: A new generation of protein database search programs. Nucleic Acids Res. 1997, 25, 3389-3402. [CrossRef] [PubMed]

15. Yoon, S.-H.; Ha, S.-M.; Kwon, S.; Lim, J.; Kim, Y.; Seo, H.; Chun, J. Introducing EzBioCloud: A taxonomically united database of 16s rrna gene sequences and whole-genome assemblies. Int. J. Syst. Evol. Microbiol. 2017, 67, 1613-1617. [CrossRef] [PubMed]

16. Babraham Bioinformatics-FastQC a Quality Control Tool for High Throughput Sequence Data. Available online: https: //www.bioinformatics.babraham.ac.uk/projects/fastqc/ (accessed on 18 May 2021).

17. Bolger, A.M.; Lohse, M.; Usadel, B. Trimmomatic: A flexible trimmer for illumina sequence data. Bioinforma. Oxf. Engl. 2014, 30, 2114-2120. [CrossRef] [PubMed]

18. Bankevich, A.; Nurk, S.; Antipov, D.; Gurevich, A.A.; Dvorkin, M.; Kulikov, A.S.; Lesin, V.M.; Nikolenko, S.I.; Pham, S.; Prjibelski, A.D.; et al. SPAdes: A new genome assembly algorithm and its applications to single-cell sequencing. J. Comput. Biol. 2012, 19, 455-477. [CrossRef] [PubMed] 
19. Pryszcz, L.P.; Gabaldón, T. Redundans: An assembly pipeline for highly heterozygous genomes. Nucleic Acids Res. 2016,44, e113. [CrossRef]

20. Challis, R.; Richards, E.; Rajan, J.; Cochrane, G.; Blaxter, M. BlobToolKit—Interactive quality assessment of genome assemblies. G3 Genes Genomes Genet. 2020, 10, 1361-1374. [CrossRef] [PubMed]

21. Seppey, M.; Manni, M.; Zdobnov, E.M. BUSCO: Assessing genome assembly and annotation completeness. Methods Mol. Biol. Clifton NJ 2019, 1962, 227-245. [CrossRef]

22. Li, W.; O’Neill, K.R.; Haft, D.H.; DiCuccio, M.; Chetvernin, V.; Badretdin, A.; Coulouris, G.; Chitsaz, F.; Derbyshire, M.K.; Durkin, A.S.; et al. RefSeq: Expanding the prokaryotic genome annotation pipeline reach with protein family model curation. Nucleic Acids Res. 2021, 49, D1020-D1028. [CrossRef]

23. Galperin, M.Y.; Wolf, Y.I.; Makarova, K.S.; Vera Alvarez, R.; Landsman, D.; Koonin, E.V. COG Database update: Focus on microbial diversity, model organisms, and widespread pathogens. Nucleic Acids Res. 2021, 49, D274-D281. [CrossRef] [PubMed]

24. Camacho, C.; Coulouris, G.; Avagyan, V.; Ma, N.; Papadopoulos, J.; Bealer, K.; Madden, T.L. BLAST+: Architecture and applications. BMC Bioinform. 2009, 10, 421. [CrossRef] [PubMed]

25. Auch, A.F.; von Jan, M.; Klenk, H.-P.; Göker, M. Digital DNA-DNA hybridization for microbial species delineation by means of genome-to-genome sequence comparison. Stand. Genomic Sci. 2010, 2, 117-134. [CrossRef] [PubMed]

26. Goris, J.; Konstantinidis, K.T.; Klappenbach, J.A.; Coenye, T.; Vandamme, P.; Tiedje, J.M. DNA-DNA hybridization values and their relationship to whole-genome sequence similarities. Int. J. Syst. Evol. Microbiol. 2007, 57, 81-91. [CrossRef] [PubMed]

27. Mishra, A.K.; Gimenez, G.; Lagier, J.-C.; Robert, C.; Raoult, D.; Fournier, P.-E. Genome sequence and description of Alistipes senegalensis sp. nov. Stand. Genomic Sci. 2012, 6, 1-16. [CrossRef] [PubMed]

28. Meier-Kolthoff, J.P.; Auch, A.F.; Klenk, H.-P.; Göker, M. Genome sequence-based species delimitation with confidence intervals and improved distance functions. BMC Bioinform. 2013, 14, 60. [CrossRef] [PubMed]

29. Chun, J.; Oren, A.; Ventosa, A.; Christensen, H.; Arahal, D.R.; da Costa, M.S.; Rooney, A.P.; Yi, H.; Xu, X.-W.; De Meyer, S.; et al. Proposed minimal standards for the use of genome data for the taxonomy of prokaryotes. Int. J. Syst. Evol. Microbiol. 2018, 68, 461-466. [CrossRef] [PubMed]

30. Rodriguez, L.M.; Konstantinidis, K.T. Bypassing cultivation to identify bacterial species: Culture-independent genomic approaches identify credibly distinct clusters, avoid cultivation bias, and provide true insights into microbial species. Microbe Mag. 2014, 9, 111-118. [CrossRef]

31. Stackebrandt, E.; Ebers, J. Taxonomic parameters revisited: Tarnished gold standards. Microbiol. Today 2006, 33 , 152.

32. Kim, M.; Oh, H.-S.; Park, S.-C.; Chun, J. Towards a taxonomic coherence between average nucleotide identity and 16s rrna gene sequence similarity for species demarcation of prokaryotes. Int. J. Syst. Evol. Microbiol. 2014, 64, 346-351. [CrossRef] [PubMed]

33. Yarza, P.; Yilmaz, P.; Pruesse, E.; Glöckner, F.O.; Ludwig, W.; Schleifer, K.-H.; Whitman, W.B.; Euzéby, J.; Amann, R.; Rosselló-Móra, R. Uniting the classification of cultured and uncultured bacteria and archaea using $16 \mathrm{~S}$ rRNA gene sequences. Nat. Rev. Microbiol. 2014, 12, 635-645. [CrossRef] [PubMed]

34. Eggermont, A.M.M.; Kicinski, M.; Blank, C.U.; Mandala, M.; Long, G.V.; Atkinson, V.; Dalle, S.; Haydon, A.; Khattak, A.; Carlino, M.S.; et al. Association between immune-related adverse events and recurrence-free survival among patients with stage iii melanoma randomized to receive pembrolizumab or placebo: A secondary analysis of a randomized clinical trial. JAMA Oncol. 2020, 6, 519-527. [CrossRef] [PubMed]

35. Derosa, L.; Routy, B.; Thomas, A.M.; Iebba, V.; Zalcman, G.; Friard, S.; Mazieres, J.; Audigier-Valette, C.; Moro-Sibilot, D.; Goldwasser, F.; et al. Intestinal Akkermansia muciniphila predicts clinical response to PD-1 blockade in patients with advanced non-small-cell lung cancer. Nat. Med. 2022, 28, 315-324. [CrossRef] [PubMed] 